\title{
SEQUENCE ANALYSIS OF THE MEMBRANE PROTEIN GENE AND NUCLEOCAPSID GENE OF PORCINE REPRODUCTIVE AND RESPIRATORY SYNDROME VIRUS ISOLATED FROM A SWINE HERD IN HUNGARY
}

\author{
I. MEDVECZKY 1 , Á. BÁLINT ${ }^{2}$, L. MAKRANSZKY ${ }^{3}$, P. STEVERINK $^{4}$ and Liesbeth JACOBS ${ }^{4 *}$
}

\begin{abstract}
${ }^{1}$ István Medveczky was until his death in November 1999 Associate Professor at the Department of Microbiology and Infectious Diseases, Faculty of Veterinary Science, Szent István University, H-1581 Budapest, P.O. Box 22, Hungary; ${ }^{2}$ Central Veterinary Institute, H-1149 Budapest, Tábornok u. 2, Hungary; ${ }^{3}$ State Control Institute for Veterinary Biologicals, Drugs and Feeds, H-1475 Budapest 10, P.O. Box 318, Hungary; ${ }^{4}$ Institute for Animal Science and Health, ID-Lelystad, P.O. Box 65, 8200 AB, Lelystad, The Netherlands
\end{abstract}

(Received May 9, 2000; accepted October 30, 2000)

\begin{abstract}
Porcine reproductive and respiratory syndrome virus (PRRSV) was isolated from blood samples taken at a pig farm in Hungary from pigs showing clinical signs of the disease. The virus (ABV 32) was identified as belonging to the European genotype by using type-specific monoclonal antibodies. This was confirmed by comparing the sequence of the membrane protein gene (ORF 6) and the nucleocapsid gene (ORF 7) with the American VR2332 and the European LV genotype reference strain, respectively. Analysis of the amino acid sequence of the ORF 6 and ORF 7 of ABV 32 revealed five amino acid changes in both ORFs when compared with LV, of which two changes in ORF 7 were only found in the Spanish isolates. Additionally, the ORF 7 sequence was compared with corresponding sequences of a total of 21 other European strains. Phylogenetic analysis using the PHYLIP package confirmed the close relationship between the Hungarian and the Spanish isolates. Of all the isolates analysed, ABV 32 and LV were the least related.
\end{abstract}

Key words: PRRS virus, membrane protein gene, nucleocapsid gene, DNA sequence analysis, swine, Hungary

Porcine reproductive and respiratory syndrome virus (PRRSV) is a small enveloped RNA virus with a single stranded positive sense genome belonging to Arteriviridae (Meulenberg et al., 1993, 1995; Meulenberg, 2000). PRRSV causes reproductive failure in sows and respiratory distress in piglets and increases the impact of opportunistic bacterial infections (Goyal, 1993). It is a relatively new disease that was first described in the USA in 1987, emerging in pigs in Europe in 1990. Since then it has spread throughout Europe and is now endemic in most pig

*Corresponding author; E-mail: C.E.Jacobs@id.dlo.nl; Fax: +31 320238668 
dense areas. The disease contributes significantly to economic losses in the pig industry. According to epidemic investigations, PRRSV was introduced to some pig farms in Hungary in 1995 by infected boars imported from Germany. From that moment on, a nation-wide serological screening programme has been conducted on pig farms importing live pigs or using imported semen for artificial insemination. In 1996, PRRSV was added to the list of notifiable diseases in Hungary. The first PRRSV strain in Hungary was recently isolated on a farm in Southeast Hungary. Using American and European type specific monoclonal antibodies, we identified the PRRSV isolate as belonging to the European type. We also determined the sequences of the ORF 6 and ORF 7 genes, confirming the results of the serological typing.

\section{Materials and methods}

\section{PRRSV isolates}

PRRSV strain ABV 32 was isolated from serum samples taken from 1day-old weakly developed piglets, weak weaning piglets and from three- to fourmonth-old piglets suffering from respiratory distress. The samples were put on ice immediately and stored at $-70{ }^{\circ} \mathrm{C}$ until virus isolation. Primary cultures of porcine alveolar macrophages grown in M6 plates as described by Wensvoort et al. (1991) were used for propagation of the isolates. Other European strains used for the comparison are listed in Table 1. A total of 21 strains were compared. We have sequenced 6 strains and sequences of 15 were retrieved from the GenBank.

\section{Immunoperoxidase monolayer assay (IPMA)}

The supernatant was removed from infected primary porcine alveolar macrophages and the cells washed once using a solution of $0.15 \mathrm{M} \mathrm{NaCl}$, after which the plates were air-dried and stored at $-20{ }^{\circ} \mathrm{C}$ until use. For the IPMA, the cells were fixed with an ice-cold solution of $4 \%$ formaldehyde in PBS at room temperature for $15 \mathrm{~min}$. Next, the cells were washed three times with washing buffer $(0.15 \mathrm{M} \mathrm{NaCl}, 0.05 \%$ Tween 80$)$ and incubated at room temperature for $1 \mathrm{~h}$ with monoclonal antibody diluted $1: 1000$ in diluting buffer $(0.5 \mathrm{M} \mathrm{NaCl}$, $0.05 \%$ Tween $80,4 \%$ horse serum). Two monoclonal antibodies were used; VO 17 and WBE 5, which reacts specifically with the American and with the European genotypes, respectively (Nelson et al., 1993; Drew et al., 1995; Magar et al., 1995). The cells were then incubated at room temperature for $1 \mathrm{~h}$ with antimouse IgG-horseradish peroxidase diluted according to the instructions of the manufacturer in diluting buffer. The cells were washed three times with washing buffer and incubated with 3-amino-9-ethyl-carbozole $(0.2 \mathrm{mg} / \mathrm{ml})$ and $0.003 \%$ $\mathrm{H}_{2} \mathrm{O}_{2}$. After staining (about $30 \mathrm{~min}$ ), the cells were washed and examined microscopically for brown staining of infected cells. 
Table 1

Virus isolates used in this report

\begin{tabular}{|c|c|c|c|c|}
\hline Identification & Origin & Date of isolation & $\begin{array}{l}\text { Accession } \\
\text { number }\end{array}$ & Code $^{1}$ \\
\hline ABV 32-13 & Hungary & 01-1999 & AF297104 & ABV32 \\
\hline Netherlands 4.1 & Netherlands & 04-1993 & AF297099 & NL931 \\
\hline Netherlands 60 & Netherlands & 05-1994 & AF297100 & NL94 \\
\hline Netherlands 3.2 & Netherlands & 04-1993 & AF297101 & NL932 \\
\hline $50-18$ & France & $11-1995$ & AF297102 & FR951 \\
\hline 49 & Denmark & $11-1995$ & AF297103 & DE95 \\
\hline $1^{2}$ & Spain & $10-1991$ & Z92530 & SP91 \\
\hline $\mathrm{L} 51 / 2 / 92^{2}$ & Spain & 11-1992 & Z92531 & SP92 \\
\hline $2.96^{2}$ & Spain & & Z92532 & SP96 \\
\hline PRRSV10² & Netherlands & & L04493 & NL \\
\hline $\mathrm{LV}^{2}$ & Netherlands & 1991 & M96262 & LV \\
\hline $\mathrm{N} 12.2^{2}$ & Netherlands & $11-1991$ & Z92533 & NL91 \\
\hline $\mathrm{N} 14.1^{2}$ & Netherlands & 03-1993 & Z92534 & NL93 \\
\hline $\operatorname{AV} 30^{2}$ & Belgium & 06-1992 & Z92708 & BE92 \\
\hline $2.72^{2}$ & Germany & & Z92537 & GE1 \\
\hline $2.25^{2}$ & Germany & & Z92538 & GE2 \\
\hline $\mathrm{H} 2^{2}$ & England & $10-1991$ & Z92535 & EN91 \\
\hline $\mathrm{NY}^{2}$ & England & $10-1992$ & Z92536 & EN92 \\
\hline $\mathrm{IX}^{2}$ & France & 01-1995 & Z92529 & FR952 \\
\hline $\mathrm{II}^{2}$ & France & 11-1991 & Z92526 & FR91 \\
\hline $\mathrm{V}^{2}$ & France & 05-1993 & Z92706 & FR93 \\
\hline
\end{tabular}

${ }^{1}$ Codes used in Fig. $1 ;{ }^{2}$ ORF sequences were obtained from the GenBank (Le Gall et al., 1998)

\section{Isolation of RNA, RT-PCR amplification and DNA sequencing}

RNA was isolated using the RNeasy RNA isolation kit (Qiagen) in accordance with the manufacturer's instructions, which involved $100 \mu 1$ of tissue culture fluid or serum sample. The RNA was eluted in $30 \mu 1$ of aqua bidest.

RNA was reverse-transcribed using a specific primer (LV119R10, Table 2). For that purpose, $4.5 \mu \mathrm{l}$ RNA solution and $1.5 \mu 1$ primer $(10 \mu \mathrm{M})$ were heated at $90{ }^{\circ} \mathrm{C}$ for $5 \mathrm{~min}$ and then left on ice. Thereafter, $2.5 \mu 1 \mathrm{RT}$ buffer $(5 \times)$, $0.5 \mu \mathrm{ldNTPs}(2 \mathrm{mM}), 0.5 \mu \mathrm{l}$ RNAsin $(20 \mathrm{U} / \mu \mathrm{l}), 0.5 \mu \mathrm{l}$ MMLV RT and $2.5 \mu \mathrm{l}$ water were added. The incubation was $45 \mathrm{~min}$ at $42{ }^{\circ} \mathrm{C}$. After denaturation for 10 min at $95^{\circ} \mathrm{C}$ the samples were cooled on ice.

Genome fragments containing the ORFs were amplified in a PCR mixture of $50 \mu \mathrm{l}$ containing $2 \mu \mathrm{l}$ cDNA, $5 \mu 12 \mathrm{mM}$ dNTPs, $3 \mu 1 \mathrm{MgCl}_{2}(25 \mathrm{mM}), 3 \mu 1$ forward primer $(10 \mu \mathrm{M}$; Table 2$), 3 \mu 1$ reverse primer $(10 \mu \mathrm{M}), 0.5 \mu 1$ Taq polymerase (Perkin Elmer) and $5 \mu 110 \times$ PCR buffer. During preparation, the samples were kept on ice. PCR conditions were $30 \sec 94^{\circ} \mathrm{C}, 30 \sec 55^{\circ} \mathrm{C}, 2 \min 72{ }^{\circ} \mathrm{C}$ for 39 cycles, followed by one cycle of $10 \min 72^{\circ} \mathrm{C}$. 
Table 2

Primers used in this report

\begin{tabular}{lllc}
\hline \multicolumn{1}{c}{ Code } & \multicolumn{1}{c}{ Sequence } & Direction & \multicolumn{1}{c}{ Location $^{1}$} \\
\hline LV19 & GGT TAA CCT TCG TCG ACT ATG & Forward & 14571 (ORF6) \\
LV18 & GAC TTT ATC CAT TGG GAT CGA AGC A & Reverse & 14673 (ORF6) \\
547760W09 & GCT GTT AAA CGA GGA GTG GT & Forward & 14553 (ORF7) \\
LV119R10 & TAG GTG ACT CAG AGG CCA CA & Reverse & 15006 (ORF7) \\
\hline
\end{tabular}

${ }^{1}$ Position based on the sequence of LV as present in the GenBank, accession number M96262

The PCR products were analysed on a $1 \%$ TAE $(0.04 \mathrm{M}$ Tris-HCl-acetate buffer, $0.001 \mathrm{M}$ EDTA, pH 8) gel and the bands were cut out from the gel. The DNA was isolated using SpinX-columns (Costar) according to the manufacturer's instructions. After precipitation, the DNA was dissolved in $10 \mu \mathrm{l}$ aqua bidest.

The PCR products were sequenced using the ABI PRISM Dye Terminator Cycle Sequence Ready Reaction kit (Perkin Elmer) in a final reaction volume of $5 \mu \mathrm{l}$ containing $1 \mu \mathrm{l}$ of primer $(2 \mathrm{mM}), 2 \mu \mathrm{l}$ DNA, and $2 \mu 1$ Term Ready Reagents. The conditions of this PCR were 1 cycle of $2 \min 96^{\circ} \mathrm{C}$ followed by 25 cycles of $10 \mathrm{sec} 96^{\circ} \mathrm{C}, 5 \mathrm{sec} 50^{\circ} \mathrm{C}, 4 \min 60^{\circ} \mathrm{C}$, followed by a cycle of $5 \mathrm{sec}$ $72{ }^{\circ} \mathrm{C}$. Purification of the PCR products was done by adding $95 \mu \mathrm{l}$ aqua bidest, $200 \mu \mathrm{l} \mathrm{EtOH} \mathrm{(96 \% ),} \mathrm{and} 20 \mu \mathrm{l} \mathrm{Na}$ acetate (3 M, pH 4.8). The precipitate was dissolved in $15 \mu 1$ Template Suppression Reagent, after which the samples were denatured for $2 \min 95^{\circ} \mathrm{C}$ and cooled on ice before being put in the sequencer.

\section{Sequence alignments and phylogenetic analysis}

The nucleotide and deduced amino acid sequences were aligned using the OMIGA program (version 1.0, Oxford Molecular Group). Phylogenetic analysis of the same alignment was performed using the PHYLIP package (Felsenstein, 1989). To construct the phylogenetic tree we used the unweighted pair-group method with arithmetic mean.

\section{Results}

\section{Immunoperoxidase monolayer assay}

After five days, the cells inoculated with the strain ABV 32 reacted only with MAb WBE5, but not with VO17. This finding indicated that ABV 32 belonged to the European genotype (results not shown). 


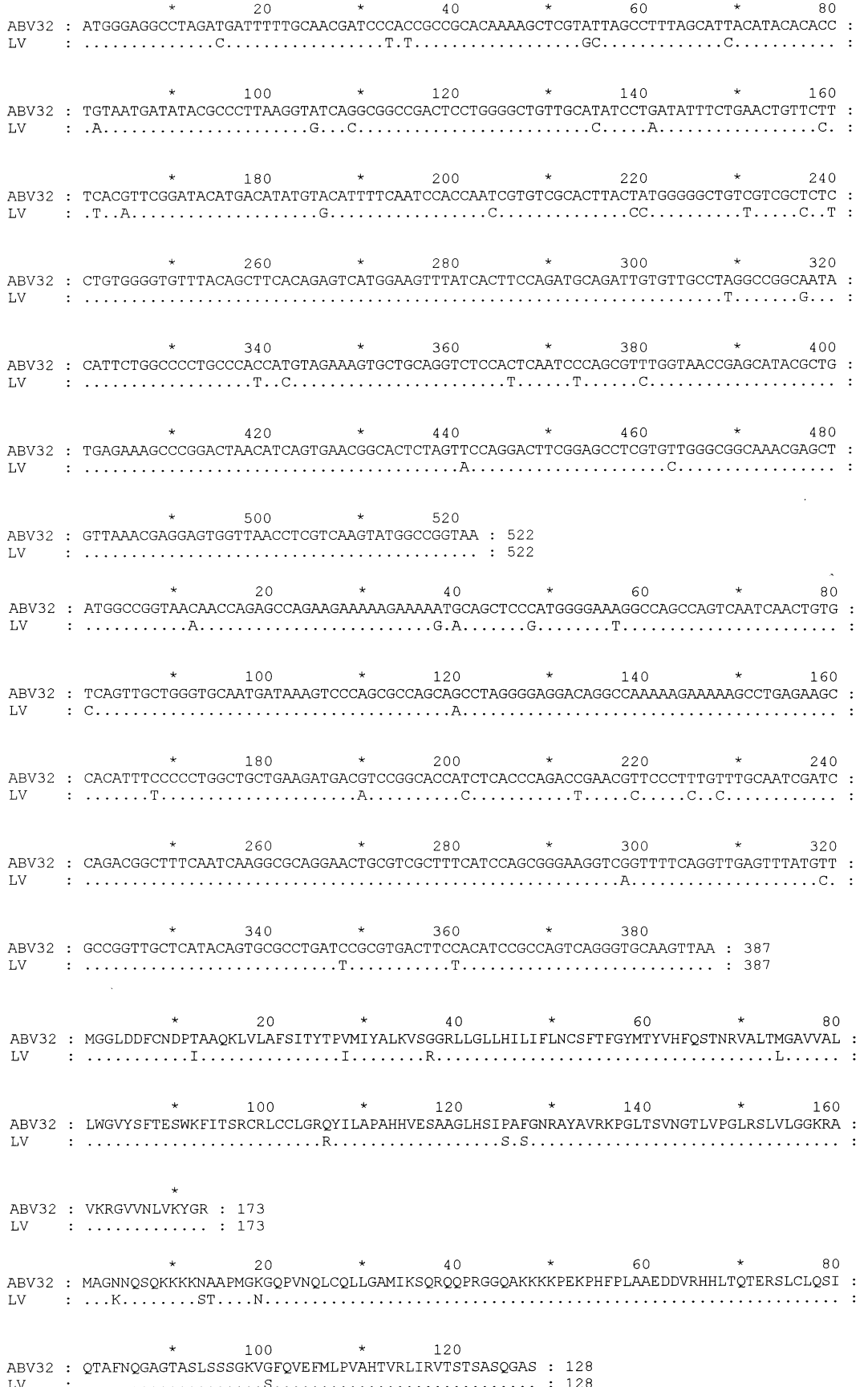

Fig. 1. Alignment of the nucleotide sequence (A) and the deduced amino acid sequence (B) of ABV 32 ORF 6 (GenBank accession number AF298882) and 7 with the European reference strain LV (Meulenberg et al., 1993). Dashes indicate sequences identical to LV 
Comparison of the ORF 6 and ORF 7 sequences of ABV 32 with the European reference strains

The nucleotide and deduced amino acid sequences of the ORF 6 and ORF 7 genes of ABV 32 were aligned and compared with the European reference strain (Fig. 1A and B). Although we found some differences, the alignment confirmed the results of the IPMA that ABV 32 belongs to the European genotype (data not shown). When the 522 nucleotides long ORF 6 sequence of ABV 32 was compared with that of LV, 29 nucleotide changes were found, five of which resulted in amino acid changes. Comparison of the ORF 7 sequences revealed 18 nucleotide changes (of the 387) also resulting in five amino acid changes (Fig. 1A and B).

\section{Phylogenetic analysis}

The sequence of ORF 7 of ABV 32 was compared with that of the strains indicated in Table 2 and their alignment used for phylogenetic analysis by means of the unweighted pair-group method with arithmetic mean. Of the sequences analysed, the phylogenetic tree clearly demonstrated the relationship of the Hungarian isolate with the three included Spanish isolates (Fig. 2).

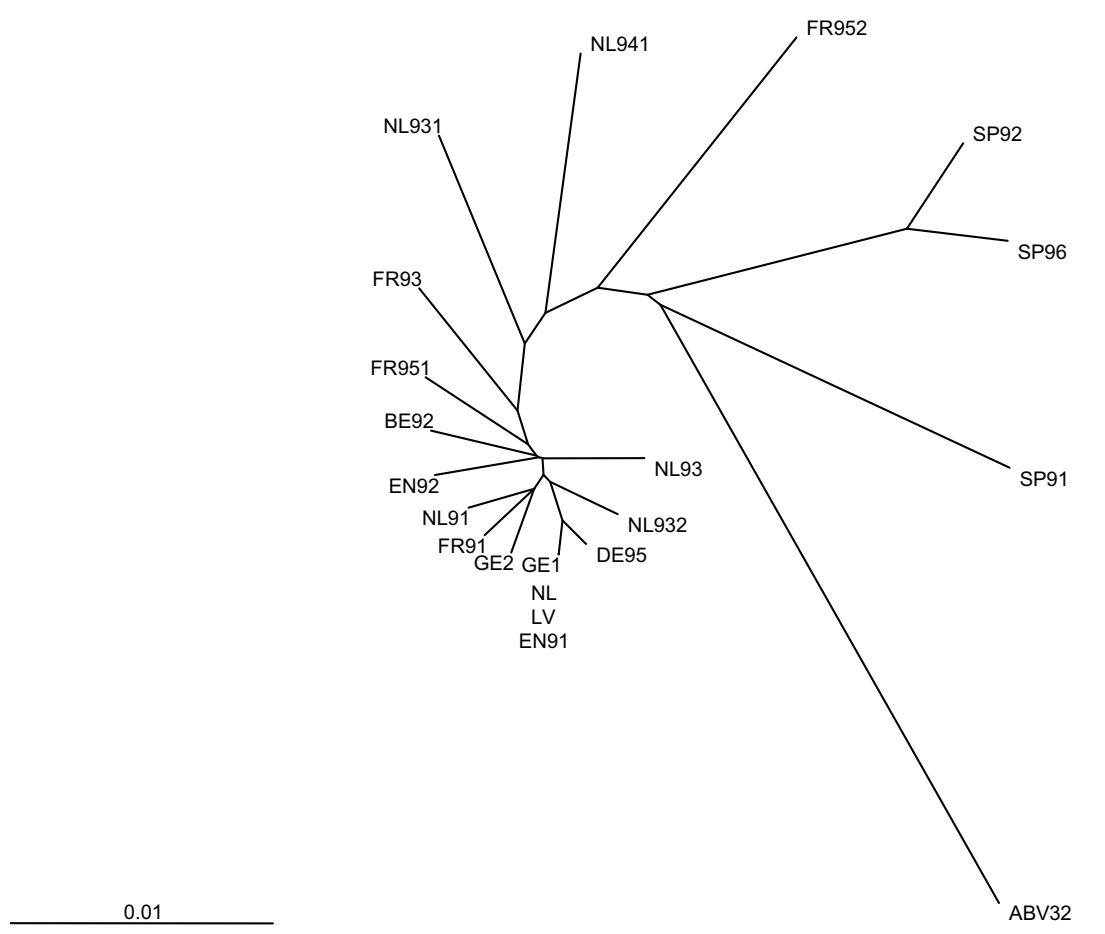

Fig. 2. Phylogenetic relationship of 21 European field isolates including the European reference strain LV based on the nucleotide sequence of ORF7. The PHYLIP program version 3.4

(Felsenstein, 1989) was used to produce the tree 


\section{Discussion}

The aim of the work described in this paper was to identify and to analyse the first Hungarian PRRSV strain and to determine its phylogenetic relationship with other European PRRSV strains. When the sequences of ORF 6 and ORF 7 were compared with that of the LV strain, the number of substitutions per nucleotide site was 0.057 for ORF 6 and 0.046 for ORF 7. However, when comparing the percentages of synonymous substitutions (of the total amount of substitutions) these were, respectively, $17 \%$ for ORF 6 and $28 \%$ for ORF 7, indicating that ORF 6 is more conserved than ORF 7. For this reason and because most sequence information is available about ORF 7, phylogenetic trees were determined by comparison of the sequences of this gene.

PRRSV infection was unknown in Hungary prior to 1995. Information from the field suggests that PRRSV was first introduced into Hungary by infected boars imported from Germany. However, phylogenetic analysis of the strain isolated in 1999 showed a closer relationship with Spanish isolates than with German isolates, supported also by a simple comparison of the amino acid sequences. Two amino acid substitutions present in the ORF 7 protein of ABV 32 were representative of three Spanish isolates as published by Le Gall et al. (1998). These were, at position 14, the substitution of threonine (T) for alanine (A, present in all the three Spanish isolates) and at position 100 serine (S) for glycine ( $G$, present in one of the Spanish isolates). Both amino acid substitutions are the result of a transition of A into G.

Another striking amino acid change was found in the Hungarian isolate at position 19 of the amino acid sequence of ORF 7 (asparagine is substituted for lysine as a result of a transversion of $\mathrm{T}$ into $\mathrm{A}$ ). Of the strains analysed and shown by us, this substitution is found only in ABV 32 and is present at the same position in all the American field isolates including the American reference strain as represented by Le Gall et al. (1998). This could indicate that the Hungarian strain is perhaps the oldest of the compared strains (Mardassi et al., 1994).

Little is known as yet about the genetic diversity of PRRSV in the field. However, to control this endemic, fast-spreading disease in Europe, insight into the antigenic variability and evaluation of occurrences of PRRSV can be of vital importance. Among the analysed strains ABV 32 was the farthest from LV, and was also the most recently isolated strain included in our analysis. Between the isolation of LV and ABV 32 is a ten-year time span indicating that genetic diversity among PRRSV isolates is increasing. Additionally, since Denmark began to use live (American type) vaccines against PRRSV, both American and European type PRRSV coexist in Danish herds. Intragenic recombination has been described for PRRSV, not only evidenced by statistical analysis (Kapur et al., 1996) but also by in vitro experiments (Yuan et al., 1999). No indications for recombination between the American type and European type PRRSV have yet been found in the field or 
in experimentally infected pigs; however, there is always a risk of new virus variants emerging by recombination. Intensive surveillance of PRRSV field strains is crucial to minimise the risk of spread of new variants of the virus in Europe.

\section{Acknowledgements}

This article is dedicated to the memory of Dr. István Medveczky, who was at IDLelystad in January 1999 when he isolated the ABV 32 strain. Dr. István Medveczky died of cancer in November 1999. We have lost not only a good scientist and veterinarian but also a good friend. The authors wish to thank Dr. L. Siig Christensen for helpful discussion.

\section{References}

Drew, T. W., Meulenberg, J. J. M., Sands, J. J. and Paton, D. J. (1995): Production, characterization and reactivity of monoclonal antibodies to porcine reproductive and respiratory syndrome virus. J. Gen. Virol. 76, 1361-1369.

Felsenstein, J. (1989): PHYLIP - Phylogeny inference package (VERSION 3.2). Cladistics 5, 164-166.

Goyal, S. M. (1993): Porcine reproductive and respiratory syndrome. Review article. J. Vet. Diagn. Invest. 5, 656-664.

Kapur, V., Elam, M. R., Pawlovich, T. M. and Murtaugh, M. P. (1996): Genetic variation in porcine reproductive and respiratory syndrome virus isolates in the Midwestern United States. J. Gen. Virol. 77, 1271-1276.

Le Gall, A., Legeay, O., Bourhy, H., Arnauld, C., Albina, E. and Jestin, A. (1998): Molecular variation in the nucleoprotein gene (ORF7) of the porcine reproductive and respiratory syndrome virus (PRRSV). Virus Res. 54, 9-21.

Mardassi, H., Mounir, S. and Dea, S. (1994): Identification of major differences in the nucleocapsid genes of a Quebec strain and European strains of porcine reproductive and respiratory syndrome virus. J. Gen. Virol. 75, 681-685.

Magar, R., Larochelle, R. and Dea, S. (1995): Antigenic comparison of Canadian and US isolates of porcine reproductive and respiratory syndrome virus using monoclonal antibodies to the nucleocapsid protein. Can. J. Vet. Res. 59, 232-234.

Meulenberg, J. J. M., Hulst, M. M., de Meijer, E. J., Moonen, P. L. J. M., den Besten, A., de Kluyver, E. P., Wensvoort, G. and Moorman, R. J. M. (1993): Lelystad virus, the causative agent of porcine epidemic abortion and respiratory syndrome (PEARS) is related to LDV and EAV. Virology 192, 62-77.

Meulenberg, J. J. M., Petersen-den Besten, A., de Kluyver, E. P., Moormann, R. J. M., Schaaper, W. M. M. and Wensvoort, G. (1995): Characterization of proteins encoded by ORFs 2 to 7 of Lelystad virus. Virology 206, 155-163.

Meulenberg, J. J. M. (2000): PRRSV, the virus. Vet. Res. 31, 11-21.

Nelson, E. A., Christopher-Hennings, J., Drew, T., Wensvoort, G., Collins, J. E. and Benfield, D. A. (1993): Differentiation of U.S. and European isolates of porcine reproductive and respiratory syndrome virus by monoclonal antibodies. J. Clin. Microbiol. 31, 3184-3189.

Wensvoort, G., Terpstra, C., Pol, J. M., ter Laak, E. A., Bloemraad, M., de Kluyver, E. P., Kragten, C., van Buiten, L., den Besten, A., Wagenaar, F., Broekhuysen, J. M., Moonen, P. L. J. M., Zetstra, T., de Boer, E. A., Tibben, H. J., de Jong, M. F., de Veld, P., van't Groenland, G. J. R., van Gennip, J. A., Voets, M. T., Verheijden, J. H. M. and Braamskamp, J (1991): Mystery swine disease in The Netherlands: the isolation of Lelystad virus. Vet. Quart. 13, 121-128.

Yuan, S., Nelsen, C. J., Murtaugh, M. P., Schmitt, B. J. and Faaberg, K. S. (1999): Recombination between North American strains of porcine reproductive and respiratory syndrome virus. Virus Res. 61, 87-98. 